\title{
Programming for Adults
}

\author{
John Welch
}

This article surveys recent programming for adults in North Carolina public libraries. Our definition of programming includes any activity offered by a library whether or not it requires a financial or in-kind contribution from the library or the active participation of library personnel. Over the past several years, programming for adults has become an increasingly important part of the regular operations of many North Carolina public libraries. For some time public libraries across the state have engaged in fundamental programming such as book reviews and film presentations. Recently, however, many newer and more innovative programs have been offered to library patrons. With the assistance and encouragement of agencies such as the North Carolina Arts Council and the North Carolina Humanities Committee, libraries have been able to take advantage of a widening range of scholars, performing artists, and exhibits. This has led to the formation of new alliances between local public libraries and colleges, universities, community colleges, and art and music institutes.

The range of program topics presented for adults is impressive. Consider this brief listing of recent programming subjects: ballet, computers, financial management, folk art and crafts, folklore, foreign affairs, fossils, heraldry, investment, Japanese folklore, mental health, music programs, signing, solar energy, and tobacco. A recent article in the Raleigh News and Observer took note of the fact that non-traditional programming is becoming a common event in many of the state's public libraries. The brief annotations that follow serve as examples of the programming being done:

John Weleh is Public Library Consultant, NC Division of State Library, Raleigh.

\section{Special Programs}

The Carteret County Library presented a program on the Revolutionary War battle of Beaufort, NC.

The Edgecombe County Memorial Library received a grant for a major presentation on the role of tobacco in North Carolina's economy. The program offered the views of an historian, a philosopher, and a political scientist as well as the viewpoints of representatives from farming, industry, and public health sectors.

In an unusual twist on film programming, the Greensboro Public Library offered a day long showing of business films for members of the local business community. Attendees were asked to evaluate the films, and those with the highest ratings were purchased for the library's collection.

The New Hanover County Public Library using a grant from the NC Board of Science and Technology presented an ambitious three month program entitled "The 80-111 Connec" tion: Understanding Microcomputers." Topics ranged from how video games affect children to the ethical aspects of computerized informa. tion. Speakers included various experts in the field as well as representatives from state and national government.

Pack Memorial Library, Asheville, offered a six-part film series featuring Dame Margot Fonteyn entitled "Magic of Dance." Both Pack Memorial and Greensboro Public Libraries hosted programs featuring members of their respective symphonic orchestras who intro duced upcoming musical works to the public.

Randolph County Public Library sponsored a two-day workshop on the principles of supervision. The workshop was presented by faculty members from North Carolina State University and was designed for first line and middle level managers.

Wayne County Public Library celebrated Black History month in 1981 by hosting a presentation of "An African Ballet" which recreated a day in the life of a Nigerian village. 
For seven summers, Onslow County's "Culture Under the Carport" series has featured everything from the Marine Band to magic shows, with the performers under the library's "bookmobile-port" and the audience under the stars.

\section{The Grassroots Arts Program ${ }^{2}$}

Several of the state's public libraries have taken advantage of the assistance offered by the Grassroots Arts Program of the North Carolina Arts Council. This program is a primary source of funds for locally initiated and community supported arts activities. The following library programs were listed in their 1981-1982 calendar of activities:

Charles A. Cannon Memorial Library, oncord, music series.

Columbus County Public Library, in cooperation with other local agencies sponsored visual and performing arts residencies in local schools.

Robeson County Public Libraries hosted the Robeson County Music Club's Sunday Afternoon Concert Series.

\section{The North Carolina Humanities \\ Committee ${ }^{3}$}

One of the most fruitful partnerships for worth Carolina public libraries has been their working relationship with the North Carolina Humities Committee. The North Carolina portedies Committee is a foundation suppurp by tax funds and private gifts whose tione is to encourage and assist public educaOver activities in the humanities for adults. grou the past several years the support of this moup has enabled the state's public libraries to followint some very impressive programs. The effort: lenburg Public Library of Charlotte and Meckwhich County conducted library study circles cussion combined scholarly teaching with disTopion of the subjects by the participants. Sacre included "The Western Concept of the Weste," "Industrialization and the Shaping of Litern Culture," and "Selecting and Using rature with Pre-School Children."

Libra In 1980, the Cumberland County Public menty began offering a still running, monuThe series entitled "The Measure of Man." exampose of this presentation was to amine the experiences of other ages and use those experiences to help understand our own times. The series contains six major sections:

1. The Greek Moment: Athens in the Fifth Century, B.C.

2. The Storied World: Europe in the High Middle Ages.

3. The Human Dimension: The Age of Renaissance and Reformation.

4. The Reach of Reason: The Enlightenment in the Eighteenth Century.

5. The Burdens of Progress: Empire and Industry in the Nineteenth Century.

6. The Broken Mirror: Changing Values in the Modern Age.

The Durham County Public Library has used its close ties to local universities to produce some exceptional programs, especially some that deal with literature:

1. "The Many Faces of Bloomsbury" consisted of a study group, a lecture series, a program of films and a photo exhibit which described and interpreted the lives and work of Virginia Woolf, E. M. Forester, Roger Fry and other members of the Bloomsbury group.

2. Another literature program used Ezra Pound's $A B C$ of Reading as an aid to help new writers become familiar with the great literature of the past.

3. Other literature programs have featured such topics as African, Oriental and European folklore and the 1920 Negro Renaissance in Harlem.

The Gaston-Lincoln Regional Library presented a program that included lectures and discussions on the historical influences that shaped Lincoln County.

"Cinema in Black" was a film/discussion series at the Greensboro Public Library with participants from the fields of history, philosophy and literature that interpreted the works of contemporary black filmmakers.

The Onslow County Public Library examined the works of Homer, Chaucer, Shakespeare and black writers in a program entitled "Heroes, Heroines, Scoundrels and Cheats: Literary Perspectives for Today."

Wayne County and Onslow County Libraries cooperated in a series on the South in film. The films "Gone with the Wind" and "The Heart is a Lonely Hunter" were used to examine Southern history, race relations and growing up in the New South.

These, then, are a few of the offerings of North Carolina public libraries in the area of 
adult programming. ${ }^{4}$ It is interesting to note that, of the wide subject variety of programs offered, the one area that seems to be neglected is science. There are probably some justifiable reasons for this which may include the difficulty and expense of presenting science programs. Also, the general inclination of public libraries to offer programming in the arts, literature or the humanities is well established. The recent success of such public television programs as "NOVA," "COSMOS," "Life on Earth" and the National Geographic Society specials indicate a reawakened interest in the various facets of science. Add to that the new national priorities on science and mathematics and the arrival of the computer and there does seem to be a new potential for public library programming. What is needed is a science counterpart to the North Carolina Humanities Committee that could provide guidance and support for such scientific programming. The State of North Carolina has set as its goal the attraction of the microelectronics industry to our area, and this would certainly be one way of preparing our citizens for this change.

\section{References}

1. News and Observer (Raleigh), 27 January 1983, p. 27A.

2. For additional information on the activities of the North Carolina Arts Council, write: North Carolina Arts Council, Department of Cultural Resources, 109 East Jones Street, Raleigh, NC 27611.

3. For additional information on the activities of the North Carolina Humanities Committee, write: North Carolina Humanities Committee, 112 Foust Bdg., UNC-G, Greensboro, NC 27412.

4. Two suggested readings are Felicia A. Carparelli, A Practical Approach to Programming. Chicago: American Library Association, 1982 ("Adult Services in Action," Number 1); and Lydia Lafleur and John S. Robotham, Library Programs: How to Select, Plan and Produce Them. Metuchen, N.J.: Scarecrow Press, 1981.

\section{DOES YOUR SUISCRIPTON AGENGY CFFR YOU... MORE?}

MORE . . . than 160,000 foreign and domestic serials?

MORE . . personalized service and flexibility from regional offices with professionals to make your serials program work better?

MORE . . e easily handled claiming?

MORE . . innovation with the world's first international online data communications system for serials?

We provide the most ... MORE often.

ERSCO SURSCRIPTION SERVICES The serials professionals.

8000 Forbes Place, Suite 204

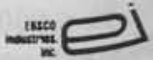

Springfield, VA 22151

(703) 321-7494/321-9630 


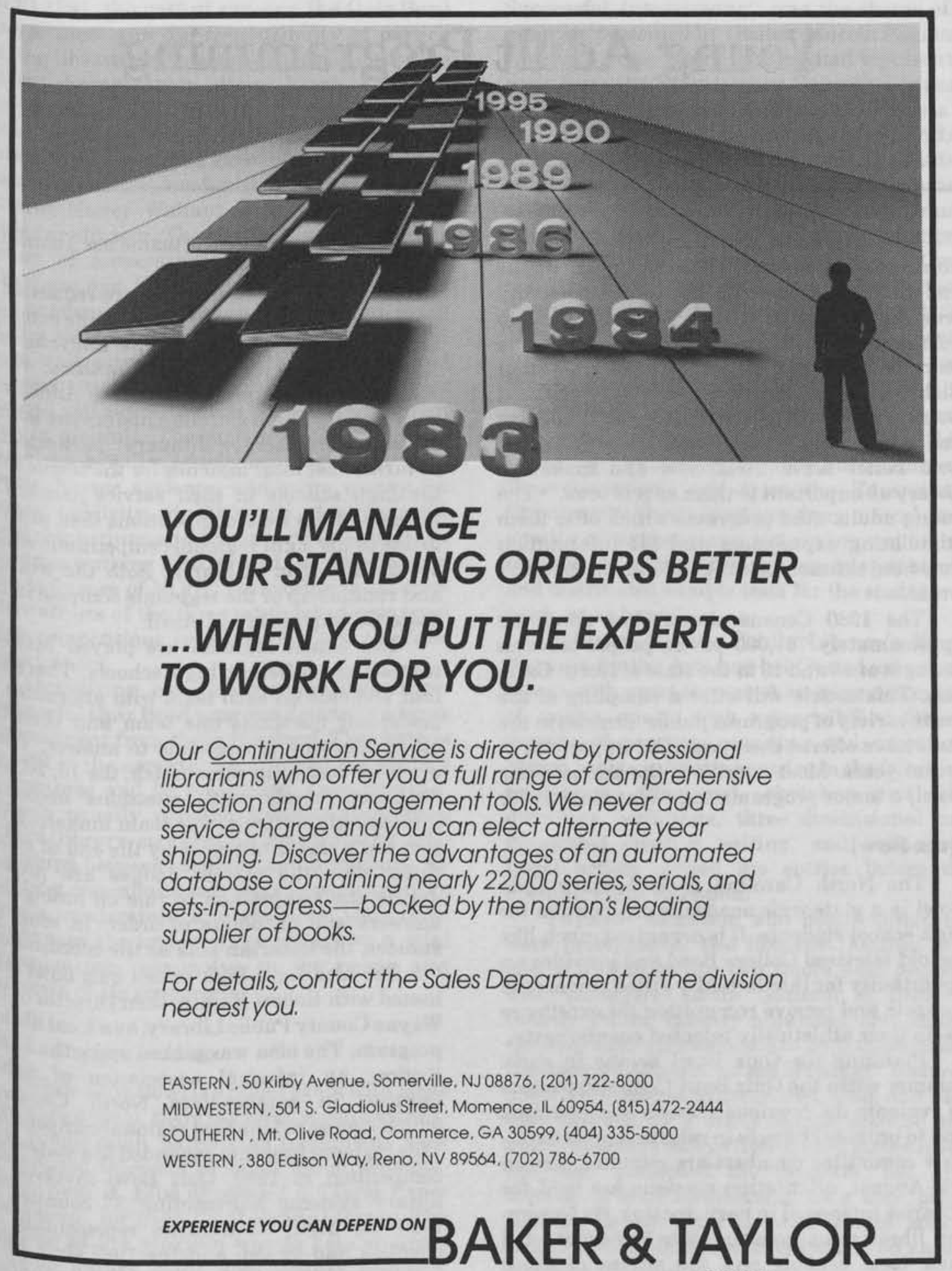

Our Continuation Service is directed by professional librarians who offer you a full range of comprehensive selection and management tools. We never add a service charge and you can elect alternate year shipping. Discover the advantages of an automated database containing nearly 22,000 series, serials, and sets-in-progress - backed by the nation's leading supplier of books.

For details, contact the Sales Department of the division nearestyou.

EASTERN . 50 Kirby Avenue. Somerville. NJ 08876, (201) 722-8000

a GRACE company 